\title{
Effect of Hydrated Lime and Cement on the Engineering Behavior of Highly Expansive Clay
}

\author{
By Fawzi Bouras ${ }^{*}$, Nouffou Tapsoba ${ }^{* *}$, Mylène Martin ${ }^{+}$, Serge Sabio ${ }^{+}$, \\ Alain Jacquet, Kevin Beck*, Naima Belayachi ${ }^{\circ}$, Marwen Bouasker ${ }^{\star}$ \\ \& Muzahim Al-Mukhtar*
}

\begin{abstract}
For long decades, soil stabilization has shown to be a sustainable and cost effective solution for road construction. Soil stabilization consists in improving physical, chemical and mechanical properties of a soil by mixing it with a well-designed amount of Hydraulic Road Binder. Hydraulic Road Binders can be defined as customized blend of clinker, cementitious materials and additions. Lime has been proven to be an efficient solution entering in the composition of Hydraulic Road Binders when dealing with highly clayey soils. The objective of this study is to compare and understand the effect of lime and cement on a highly expansive clayey soil using a comprehensive series of laboratory tests. The not natural clayey made soil was treated with theoretical dosage rates of lime and Portland cement (CEM I $52.5 \mathrm{~N}$ ) in order to study the changes in the main geotechnical properties and mineralogical composition. Plasticity index, volumetric swelling and unconfined compressive strength measurements were performed with different binder's additions. The experimental results indicate improvement in the geotechnical properties of the treated clayey soil with the binders used. The lime addition induces a significant improvement at short terms in soil properties by reducing plasticity. These improvements can be attributed to the cation exchange and the flocculation-agglomeration of the clay particles due to the lime addition. However, a higher increasing of the unconfined compressive strength is noted with cement addition. The hydration of added cement produced calcium hydrates, which are responsible for the improvement in the strength properties of the treated soils. Volumetric swelling is reduced due to the two binder additions. Cation exchange and the development of lime's pozzolanic reaction and the hydration of cement participate to reduce the absorption capacity of clay minerals in the treated soil. Mineralogical tests focused on X-ray diffraction are also investigated. Results testify changes operated in the treated soils as they show new reflections with cement and lime treatment corresponding to calcium aluminate hydrates $(\mathrm{CAH})$ and calcium silicate hydrates $(\mathrm{CSH})$.
\end{abstract}

Keywords: Cement, Expansive Clay, Hydration, Lime, Soil Treatment.

*PhD Student, University of Orleans, France.

R\&D Project Manager, LafargeHolcim, France.

${ }^{*}$ R\&D Project Manager, LafargeHolcim, France.

${ }^{+}$Specialist - Research Engineer, LafargeHolcim, France.

Research Engineer, LafargeHolcim, France.

-Associate Professor, University of Orleans, France.

Associate Professor, University of Orleans, France.

^Associate Professor, University of Orleans, France.

*Emeritus Professor, University of Orleans, France. 


\section{Introduction}

The purpose of soil treatment is to improve the geotechnical properties of a soil when it does not achieve, in its natural state, the criteria required in civil engineering constructions. Expansive soils are a worldwide problem and occur in various types of climates and locations (Vakili et al. 2013, Ikeagwuani and Nwonu 2019). Clay particles cause volumic changes of expansive soils that can generate damages when subjected to moisture fluctuations on road infrastructures (AlMhaidib 2006, Khemissa and Mahamedi 2014). The annual cost of damages induced from these types of soils is estimated to several billions of dollars worldwide (Jones and Jefferson 2012, Qi and Vanapalli 2015). Various techniques such as chemical stabilization have been developed in past years to improve their low geotechnical properties.

In order to improve the rate of reuse of the in situ clayey soils in road construction, hydraulic road binders containing lime and cement have been developed across the world. The composition of those hydraulic road binders depends on their application range and soil's characteristics. In fact, Lime is a compound traditionally used to overcome expansive soil's deficiencies (Al-Rawas et al. 2005, Ikeagwuani and Nwonu 2019). Generally, small additions of lime in clayey soils induce improvements in engineering properties through two geochemical reactions: cation exchange and flocculation at short-term reaction for soil modification and pozzolanic reaction at long-term reaction for soil stabilization. However, the mineralogical composition of the soil can affect the effectiveness of lime and the amount needed can be significant (Lasledj 2009, AlMukhtar et al. 2014). In addition, the pozzolanic reaction takes place over a long period of time. The strength of lime-treated soils is usually studied for curing period of 90 days up to 180 days. Baldovino et al. (2019) optimized the evolution of strength lime stabilized soils with curing time up to 360 days. Therefore, the slow development of strength properties and the insufficient bearing capacity in some applications can be an impediment to its use.

Cement based solutions are commonly used in soil treatment and induces improvements in the geotechnical properties of the treated soil, particularly to enhance strength and bearing capacity to avoid the settlement of soft soil or to reduce swelling of expansive soils (Bagarre 1990, Joel and Agbede 2010, Sasanian and Newson 2014, Mengue et al. 2017). However, cement can produce expansive mineral such as ettringite and induce volume instability over time (VerásteguiFlores and Di Emidio 2014). In addition, better improvements of the mechanical properties of expansive clay were obtained with lime-cement mixture treatment (Khemissa and Mahamedi 2014). Other additives such as pozzolan and silica fume can also be used to optimize the amount of cement addition, cost, curing time and improve engineering properties (Goodarzi and Salimi 2015, Vakili et al. 2013, Kalkan 2011). Moreover, in recent years, researchers are taking interests on application of industrial waste by-products in combination with lime and cement stabilizers including coal waste (Modarres and Nosoudy 2015), fly ash and bagasse ash (Sumesh and al. 2010, Dang et al. 2015, Dang et al. 2016b), bagasse 
fibres (Dang et al. 2016a) to improve the soils properties and reduce environmental problems due to waste deposing (Ikeagwuani and Nwonu 2019).

The aim of the experimental work presented in this paper is to evaluate individually the effectiveness of lime and cement additions on the engineering behavior (plasticity, swelling pressure and unconfined compressive strength) of a not natural made and highly expansive clayey soil. Dosage rates used in this study are theoretical and do not represent real context. The binder-clay reactions are studied by following the development and progression of lime's pozzolanic reaction and cement hydration with curing time and various amounts of binder additions using X-ray diffraction.

\section{Materials and Methods}

\section{Clay Soil}

The soil used in this study is a clayey soil presenting a high plasticity index $(\mathrm{PI}=266 \%)$ and commercially called Impersol. It is supplied by "Société Française des Bentonite et Dérivés" and commonly used to seal the bottom of the basins thanks to its high plasticity and significant swelling. Table 1 presents the Impersol's chemical composition and shows that $\mathrm{Na}^{+}$ions are the exchangeable cation with $2.26 \%$ of $\mathrm{Na}_{2} \mathrm{O}$. This content can explain the ability of Impersol to absorb water (Lasledj and Al-Mukhtar 2008).

The mineralogical composition of Impersol is given in Table 2. It is composed of smectite (48\%), kaolinite (38\%) and non-clay-minerals (14\%) (AlMukhtar et al. 2010). The choice of this soil for this study is motivated by the fact that this "not natural made soil" presents a high content of clay minerals $(86 \%)$ and particularly an expansive clay (smectite) that allows to better understand the clay-binder reaction and to determine the binders that are efficient in improving the geotechnical properties of the highly expansive clayey soil. However, the small amount of available soil for this study allowed us to achieve only the standard Proctor test (NF P 94-093) of the untreated soil. The untreated soil's optimum moisture content (OMC) and the maximum dry density (MDD) were determined used for different treatments studied. Moreover, using the same OMC and MMD for all tested samples allows to compare easily the obtained results as only one parameter (the amount of binder added) changes during the study. The main geotechnical properties of the Impersol are presented in Table 3.

Table 1. Chemical Composition (\%) of Impersol, by XRF

\begin{tabular}{|c|c|c|c|c|c|c|c|c|c|}
\hline $\mathrm{SiO}_{2}$ & $\mathrm{Al}_{2} \mathrm{O}_{3}$ & $\mathrm{Fe}_{2} \mathrm{O}_{3}$ & $\mathrm{CaO}$ & $\mathrm{MgO}$ & $\mathrm{K}_{2} \mathrm{O}$ & $\mathrm{Na}_{2} \mathrm{O}$ & $\mathrm{TiO}_{2}$ & others & LOI* \\
\hline 39.7 & 20.2 & 6.4 & 4.5 & 1.2 & 0.2 & 2.3 & 0.8 & $<0.05$ & 24.8 \\
\hline
\end{tabular}

*Loss on ignition.

Table 2. Mineralogical Composition (mass\%) of Impersol

\begin{tabular}{|c|c|c|c|c|c|c|}
\hline Mineral & Smectite & Kaolinite & Quartz & Calcite & Goethite & Anatase \\
\hline Content & 48 & 38 & 3.2 & 3.4 & 6.4 & 1 \\
\hline
\end{tabular}

Source: Al-Mukhtar et al. 2010. 
Table 3. The Geotechnical Properties of Impersol

\begin{tabular}{|l|c|}
\hline Property & Test value \\
\hline Liquid limit (\%) & $270 \pm 6.5$ \\
\hline Plastic limit (\%) & $43.4 \pm 1.3$ \\
\hline Plasticity index (\%) & $226.6 \pm 5.2$ \\
\hline$D_{\max }(\mathrm{mm})$ & 0.71 \\
\hline Particle size passing at $80 \mu \mathrm{m}(\%)$ & 68.17 \\
\hline Methylene blue value $(\mathrm{g} / 100 \mathrm{~g})$ & $25 \pm 0.5$ \\
\hline $\mathrm{pH}$ & $10.7 \pm 0.05$ \\
\hline Optimum moisture content $(\%)$ & 42 \\
\hline Maximum dry density $\left(\mathrm{g} / \mathrm{cm}^{3}\right)$ & 1.2 \\
\hline Swelling pressure $(\mathrm{kPa})^{*}$ & $1153 \pm 87$ \\
\hline Unconfined compressive strength $(\mathrm{kPa})^{*}$ & $224 \pm 8$ \\
\hline French soil classification $(\mathrm{GTR})$ & $\mathrm{A} 4$ \\
\hline
\end{tabular}

*At optimum Proctor compaction; GTR (French "Guide des terrassements routiers").

\section{Hydrated Lime}

The lime used is a very fine and pure hydrated lime. X-ray diffraction indicates the presence of only two mineralogical phases, portlandite and calcite. Thermogravimetric analysis showed that lime consisted mainly of portlandite $(94.5 \%)$ with traces of calcite $(5.5 \%)$. The laser granulometry of the lime indicates a passing at $80 \mu \mathrm{m}$ of $98.7 \%$. The lime used has an important Blaine specific surface area of $18,820 \mathrm{~cm}^{2} / \mathrm{g}$.

\section{Portland Cement}

The Portland cement (CEM I 52.5 N CE) used in this study is produced by LafargeHolcim company. It has a Blaine specific surface of $3,740 \mathrm{~cm}^{2} / \mathrm{g}$ and a passing at $80 \mu \mathrm{m}$ of $99.9 \%$. The results of XRF chemical characterization of the cement is presented in Table 4.

Table 4. Chemical Composition (\%) of Portland Cement Used, by XRF

\begin{tabular}{|c|c|c|c|c|c|c|}
\hline $\mathrm{SiO}_{2}$ & $\mathrm{Al}_{2} \mathrm{O}_{3}$ & $\mathrm{Fe}_{2} \mathrm{O}_{3}$ & $\mathrm{CaO}$ & $\mathrm{MgO}$ & $\mathrm{K}_{2} \mathrm{O}$ & $\mathrm{Na}_{2} \mathrm{O}$ \\
\hline 20.01 & 5.14 & 2.88 & 64.1 & 1.01 & 0.98 & 0.2 \\
\hline $\mathrm{SO}_{3}$ & $\mathrm{TiO}_{2}$ & $\mathrm{Mn}_{2} \mathrm{O}_{3}$ & $\mathrm{P}_{2} \mathrm{O}_{5}$ & $\mathrm{SrO}$ & Others & LOI* \\
\hline 3.16 & 0.26 & 0.12 & 0.22 & 0.02 & 0.28 & 1.62 \\
\hline
\end{tabular}

*Loss on ignition.

\section{Mixtures Preparation}

Impersol is a not natural made soil in the powder form with a very high plasticity index. In its wet state, it is tacky and sticky. The addition of binders to the wet soil does not provide homogeneous mixtures. Mixing is done using a spatula because the soil sticks to the kneader. The experimental procedure chosen to prepare the soil treated samples and to perform various tests started by ovendried the soil at $105^{\circ} \mathrm{C}$ during 24 hours and to cool down it at least for 6 hours and 
then to mix it with binders until obtaining a uniform color. After that, water is added to reach the desired water content. The samples are thoroughly mixed in order to obtain homogenous mixtures. The soil was treated with $6 \%, 10 \%$ and $20 \%$ of cement and lime by dry weight of soil.

\section{Atterberg Limits}

The Atterberg limits of untreated and treated soil were determined according to NF P094-51. Different amounts of water were added to the dry soil-binder mixtures and full mixing was carried out until a homogenous wet soil-binder mixture without lumps was obtained. The Atterberg limits were performed directly after at the moment where the samples became visually and texturally homogeneous.

\section{Unconfined Compressive Strength (UCS)}

The unconfined compressive strength tests were carried out on cylindrical specimens (50 mm diameter, $100 \mathrm{~mm}$ length). For each treatment, three samples were prepared. Binders were mixed with dry soil and then water was added until it reached the $\mathrm{OMC}$ of untreated soil $(\mathrm{OMC}=42 \%)$. The maximum dry density of the untreated Impersol was achieved by compaction. Table 5 shows dry densities obtained after samples confection. Samples were sealed by wrapping in cling-film to minimize moisture loss during a cure of 28 days at $20^{\circ} \mathrm{C}$. The unconfined compressive strength was measured using a mechanical press at the rate of 0.1 $\mathrm{mm} / \mathrm{min}$.

Table 5. Dry Densities of Untreated and Treated Impersol Samples

\begin{tabular}{|c|c|c|c|c|c|c|c|}
\hline Binder & - & \multicolumn{3}{|c|}{ Lime } & \multicolumn{3}{c|}{ Cement } \\
\hline Binder addition & $0 \%$ & $6 \%$ & $10 \%$ & $20 \%$ & $6 \%$ & $10 \%$ & $20 \%$ \\
\hline Dry density $(\mathrm{g} / \mathrm{cm} 3)$ & 1.181 & 1.179 & 1.178 & 1.181 & 1.177 & 1.182 & 1.181 \\
\hline
\end{tabular}

\section{Swelling Pressure}

The preparation of the soil-binder mixtures for the swelling pressure was similar to the unconfined compressive strength sample preparation. Swelling pressure tests were carried out on cylindrical specimens placed in a mold of 65 $\mathrm{mm}$ diameter and $10 \mathrm{~mm}$ length (Khattab 2002). To achieve the MDD, the mixtures were compacted in the mold. Swelling pressure is determinated by reading the displacement of the torque ring using a dial gauge with an accuracy of $0.01 \mathrm{~mm}$. The pressure exerted by the sample during its swelling and causing the displacement of the torque ring is calculated from the known torque ring characteristics. Swelling pressure was carried out on soil samples separately blended with $6 \%, 10 \%$ and $20 \%$ of lime and cement after 1.5 hours, 2 days and 28 days of curing at $20^{\circ} \mathrm{C}$. 
$X$-ray Diffraction (XRD) Tests

Changes in the mineralogy of the treated Impersol was determined on soil samples treated with 6\%,10\% and 20\% of lime and cement after 1, 7 and 28 days of curing at $20^{\circ} \mathrm{C}$. The X-ray diffraction was performed on the same samples that were prepared to measure the unconfined compressive strength (UCS). Samples were ground and sieved at $63 \mu \mathrm{m}$ and then analyzed in XRD.

\section{Results and Discussion}

\section{Effect of Lime and Cement Additions on Atterberg Limits}

Figure 1 shows that the Atterberg limits evolve so that the plasticity limit (PL) increases very slightly with binder additions while the liquid limit (LL) decreases considerably. This decrease in the liquid limit is explained by the flocculationagglomeration phenomena that occur immediately after the incorporation of lime (Cabane 2004, Al-Mukhtar et al. 2010, Maubec 2010) or cement into the soil (Khemissa and Mahamedi, 2014). These results show also that the plastic index (PI = LL - PL) which measures the plasticity behavior of Impersol is significantly improved with lime and cement treatments.

Figure 1. Effect of Lime and Cement Additions on Atterberg Limit

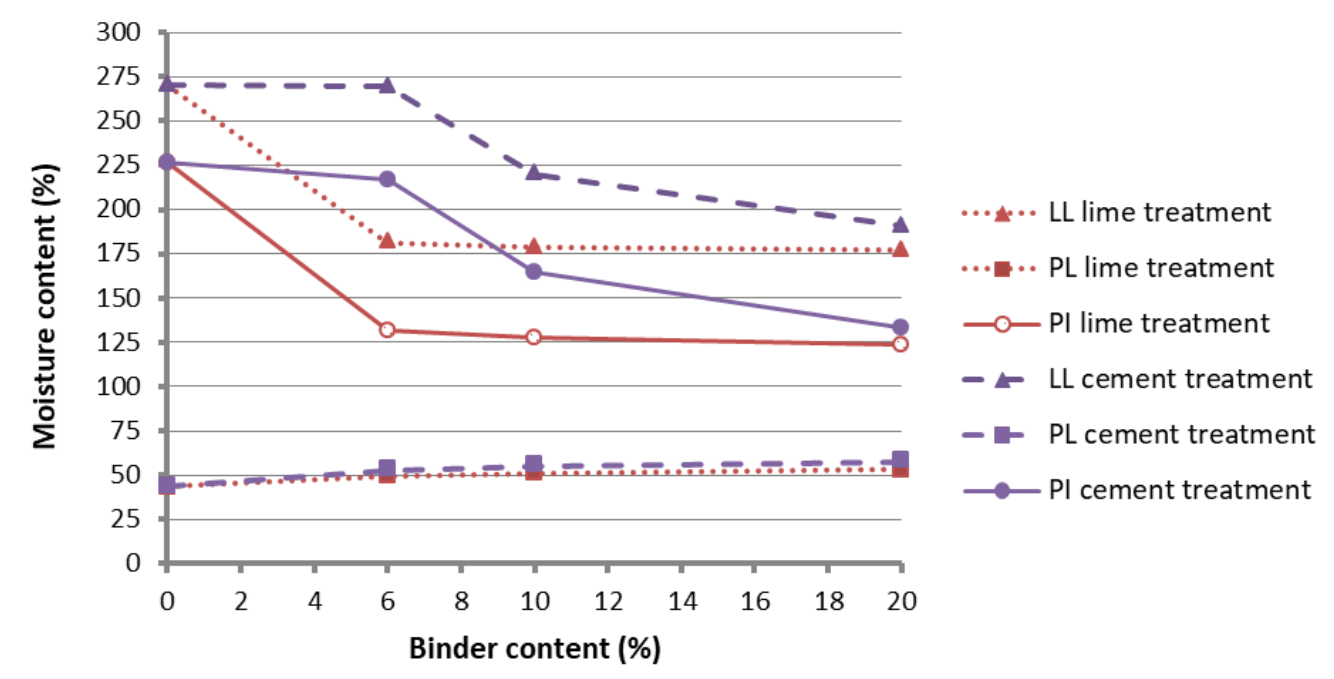

Tested samples of Impersol treated with lime show that the addition of $6 \%$ lime leads to big changes in the soil plasticity index, which drops, from $227 \%$ to $132 \%$. For higher additions of lime changes in PI are very limited $\left(\mathrm{PI}_{6 \% \text { lime }}=\right.$ $132 \%, \mathrm{PI}_{10 \% \text { lime }}=127 \%, \mathrm{PI}_{20 \% \text { lime }}=124 \%$ ). The percentage of $6 \%$ of lime added can be considered as that induces optimal improvement in the plasticity of the treated Impersol. It is called "lime fixation point" which refers to the saturation limit of the clay particles in $\mathrm{Ca}^{2+}$. 
In cement treatment, the liquid limit of the treated soil does not change with $6 \%$ addition (LL is about $270 \%$ ). It begins to fall beyond $6 \%$ addition of cement and continues to decrease with increasing cement content $\left(\mathrm{LL}_{10 \% \text { cement }}=220 \%\right.$, $\mathrm{LL}_{20 \% \text { cement }}=191 \%$ ). Results show that the improvement of plasticity with cement treatment is less important compared to lime treatment. In fact, the soil reaches a plasticity index equal to $133 \%$ with $20 \%$ of cement while it drops to $132 \%$ with only $6 \%$ of lime. This can be attributed to the effectiveness of the binders in flocculating clay particles. This behavior (flocculation) is related to clay particle saturation and therefore to the amount of calcium cation provided by the binder. These reductions in plasticity index suggest that the treated soil become easily workable and friable.

\section{Effect of Lime and Cement Additions on Unconfined Compressive Strength}

Figure 2 shows the results of unconfined compressive strength of untreated and treated Impersol with different amounts of lime and cement after 28 days of cure at $20^{\circ} \mathrm{C}$. Results show an increase of unconfined compressive strengths UCS depending on the binder considered and its content. Indeed, with $6 \%$ of cement and lime the resistances are almost the same, about $0.75 \mathrm{MPa}$, while at $10 \%$ and $20 \%$ of cement, the resistances obtained are 1.5 and 2.25 times greater compared to those obtained with lime treatment. Beyond $6 \%$ of cement, the improvement and the resistance gain are important $\left(\mathrm{UCS}_{10 \% \text { cement }}=2.68 \mathrm{MPa}\right)$. The increase in unconfined compressive strengths for cement-treated soil is related to the hydration of the cement itself and thus to the formation of calcium silicate hydrates $(\mathrm{CSH})$ or calcium aluminate hydrates $(\mathrm{CAH})$ that bind the clay particles together (cementing) and increase their cohesion. Results show that this increasing of UCS is depending on the amount of cement added.

Figure 2. Unconfined Compressive Strength of Untreated and Treated Impersol after 28 Days of Cure

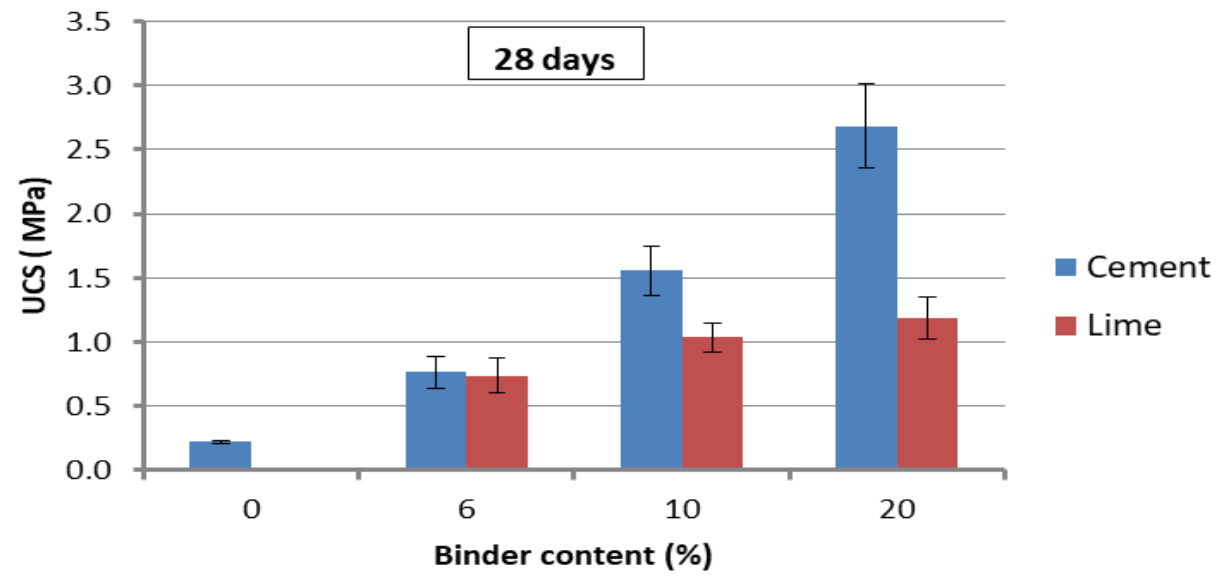

The development of resistance with lime treatment seems less dependent on the lime content. Indeed, little improvement is visible between $10 \%$ and $20 \%$ of added lime $\left(\mathrm{UCS}_{10 \% \text { lime }}=1.04 \mathrm{MPa}, \mathrm{UCS}_{20 \% \text { lime }}=1.19 \mathrm{MPa}\right)$. This can be 
explained by the slowness of the pozzolanic reaction which leads to the much more gradual formation over time of calcium hydrates responsible for the development of the mechanical resistance of the treated soil.

Effect of Lime and Cement Additions on Swelling Pressure

Table 6. Effect of Lime and Cement on Swelling Pressure of Treated Soil

\begin{tabular}{|c|c|c|c|}
\hline \multicolumn{2}{|c|}{} & \multicolumn{2}{c|}{ Swelling pressure $(\mathrm{kPa})$} \\
\hline \multicolumn{2}{|c|}{ Untreated soil } & \multicolumn{2}{c|}{$1,153 \pm 87$} \\
\hline \multicolumn{2}{|c|}{ Curing time } & $\mathbf{1 . 5}$ hours & $\mathbf{2}$ days \\
\hline \multirow{3}{*}{ Cement } & $6 \%$ & $76 \pm 12$ & 0 \\
\cline { 2 - 4 } & $10 \%$ & 0 & 0 \\
\cline { 2 - 4 } & $20 \%$ & 0 & 0 \\
\hline \multirow{3}{*}{ Lime } & $6 \%$ & $152 \pm 35$ & 0 \\
\cline { 2 - 4 } & $10 \%$ & 0 & 0 \\
\cline { 2 - 4 } & $20 \%$ & 0 & 0 \\
\hline
\end{tabular}

Table 6 shows the effect of cement and lime on swelling pressure of treated Impersol after 1.5 hours and 2 days of curing at $20^{\circ} \mathrm{C}$. Swelling pressure measured on untreated soil decreases immediately (1.5 hours) from $1,153 \mathrm{kPa}$ to $152 \mathrm{kPa}$ and $76 \mathrm{kPa}$ with $6 \%$ of lime and cement, respectively. However, swelling pressure is totally eliminated with $10 \%$ and $20 \%$ of lime and cement. Lime and cement due to the cation exchange reaction reduces the water absorption capacity of calcium saturated clay. Therefore, the swelling characteristic of this treated soil decrease quickly as can be seen after 1.5 hours. This decrease is more important with cement addition and can be attributed to cement hydration and calcium hydrates formed that cover and line the surface of clays particles and inhibit their swelling.

Results show a significant effect of curing time with the addition of $6 \%$ of binders. In fact, swelling pressure dropped to zero after 2 days curing. Measurements conducted after 28 days confirm that the swelling pressure is always zero. Pozzolanic reaction and cementitious bonding produced overtime between clay minerals and lime participate to decreasing swelling pressure (Khemissa and Mahamedi, 2014). Moreover, portlandite produced during cement hydration can contribute to the decrease of the swelling property of cement treated soil owing to continuous cation exchange reaction.

\section{Mineralogical Evolution of Lime and Cement Treated Impersol}

The evolution of the mineralogy of treated Impersol was carried out on soil samples treated with $6 \%, 10 \%$ and $20 \%$ lime and cement after 1, 7 and 28 days of curing at $20^{\circ} \mathrm{C}$.

Figure 3 shows the X-ray diffraction patterns of Impersol treated with $10 \%$ and $20 \%$ of lime (L) for 1, 7 and 28 days of curing. Results show new reflections corresponding to calcium aluminate hydrate $(\mathrm{CAH})$ at d-spacing of $7.61 \AA(2 \theta=$ 
$11.8^{\circ}$ ) in samples that contains $10 \%$ and $20 \%$ of lime. The new hydrate formed is $\mathrm{Ca}_{4} \mathrm{Al}_{2} \mathrm{CO}_{9} .11 \mathrm{H}_{2} \mathrm{O}$ and the intensities of its peaks increased with increasing lime content and curing time. Pozzolanic reaction between lime and clay minerals is more important when lime increases and starts in short term. In fact, reflections of CAH appeared after 7 days with $10 \%$ of lime addition while it appeared after 1 day with a lime content of $20 \%$. This new mineral is responsible for the increasing in compressive strength of lime treated Impersol over time.

Figure 3. X-ray Diffractions of Untreated and Treated Impersol with Lime

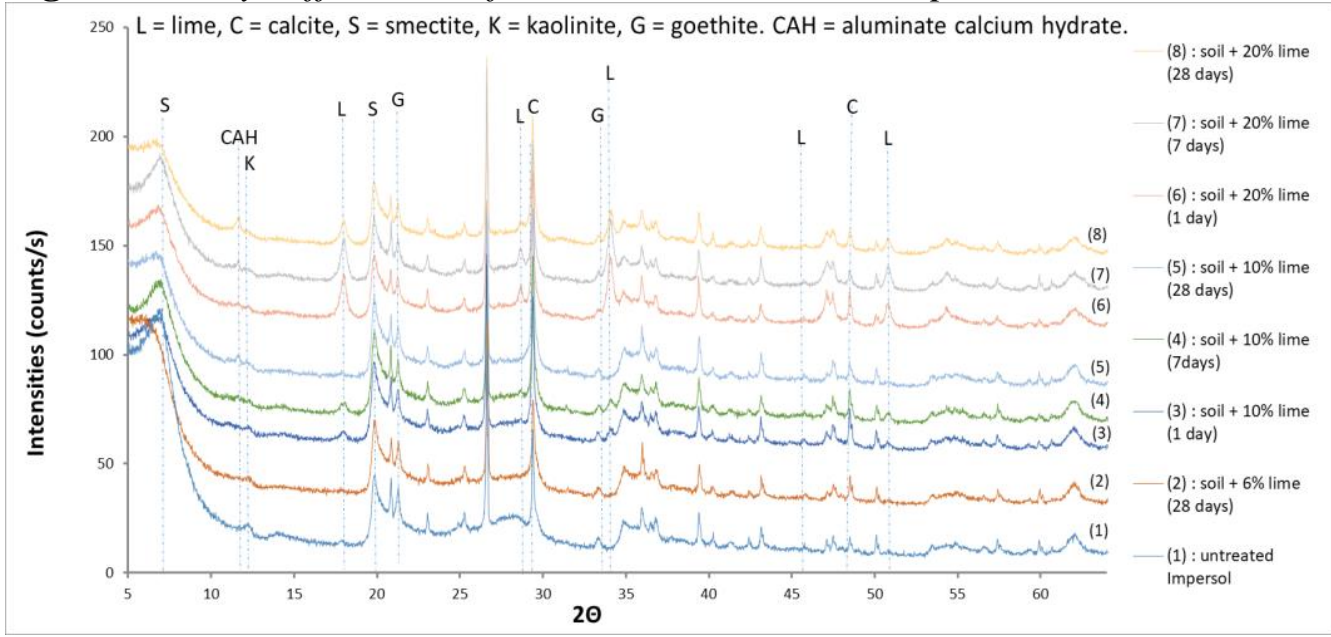

$\mathrm{CaCO}_{3}$ reflections are present in X-ray diffraction patterns of untreated soil. Results show that calcite reflections increase with curing time and lime content. This can be explained by lime carbonation during the cure (Al-Mukhtar et al. 2012).

Reflections corresponding to unconsumed lime are present at lime content of $10 \%$ and $20 \%$ after 1 day and 7 days of cure. These reflections disappear after 28 days of treatment at $10 \%$ of lime, while at $20 \%$ of lime added, free lime reflections are still present. These results demonstrate that pozzolanic reaction is progressing with time by consuming free lime and producing new calcium aluminate hydrate. This reaction between lime and clay particles is slow at $20^{\circ} \mathrm{C}$.

At $6 \%$ of lime addition, reflections of free lime and $\mathrm{CAH}$ are not visible. This can be explained by the clay particles that absorb all the calcium provided by lime for cation exchange. In fact, particles of smectite contained in Impersol present a high cation exchange capacity (100 meq/100g) (Lasledj 2009) and 6\% of lime does not satisfy the affinity of this soil for inter-lamellar calcium exchange. There is no enough calcium available for pozzolanic reaction. The quantity of lime necessary to form visible hydrates in XRD is then not ensured with $6 \%$ of lime addition.

X-ray diffraction patterns of lime treated Impersol indicate that lime addition cause a decrease in clay minerals' intensities (smectite and kaolinite). This decrease can be explained by the fact that lime treatment affects the structure of clay particles due to an attack by lime on clay and a destruction of clay layers to produce new hydrate products. Clays are consumed and the hydrates formed cover 
clay minerals and thereby decrease their reflection intensities (Lasledj and AlMukhtar 2008, Goodarzi et al. 2016). It also can be attributed to flocculated particles that tend to show less reflection intensities caused by a decrease in the reflection of incident ray when the structure is less oriented due to particles agglomeration-flocculation (Ouhadi et al. 2010, Goodarzi et al. 2016). These changes in clay structure explain the results presented in Table 6 where a reduction of lime treated Impersol capacity for swelling and expansion was observed. A higher reduction of clay reflection intensities occurred with curing time and is correlated to the progressing of pozzolanic reaction that produces newer cementing products and consumes clays (smectite and kaolinite) overtime.

Figure 4 shows the X-ray diffraction patterns of Impersol treated with $10 \%$ and $20 \%$ of cement for 1,7 and 28 days of curing. The results show the formation of new crystalline cementitious mineralogical phases. Calcium aluminate hydrate $(\mathrm{CAH})$ corresponding to monocarbo-aluminate at d-spacing of $7.57 \AA\left(2 \theta=11.7^{\circ}\right)$ is observed. Reflections of ettringite at d-spacing of $9.74 \AA\left(2 \theta=9.1^{\circ}\right)$ and $5.6 \AA$ $\left(2 \theta=15.8^{\circ}\right)$ are present in X-ray diffraction patterns of treated samples. At dspacing of $5.6 \AA\left(2 \theta=15.8^{\circ}\right)$ and $3.1 \AA\left(2 \theta=29^{\circ}\right)$ tobermorite which is a calcium silicate hydrate $(\mathrm{CSH})$ can be identified. However, tobermorite reflections are merged at these two d-spacing with ettringite and calcite, respectively. These products, resulting from the hydration of cement, appear after 1 day of cure and their intensity increases with cement content and curing time. Indeed, treatment with $20 \%$ of cement present higher reflections intensities for those products compared to treatment with $10 \%$ of cement. These new hydrates formed enhance the bonding of solid phase in soil and progress the UCS values of treated Impersol.

Figure 4. X-ray Diffractions of Untreated and Treated Impersol with Cement

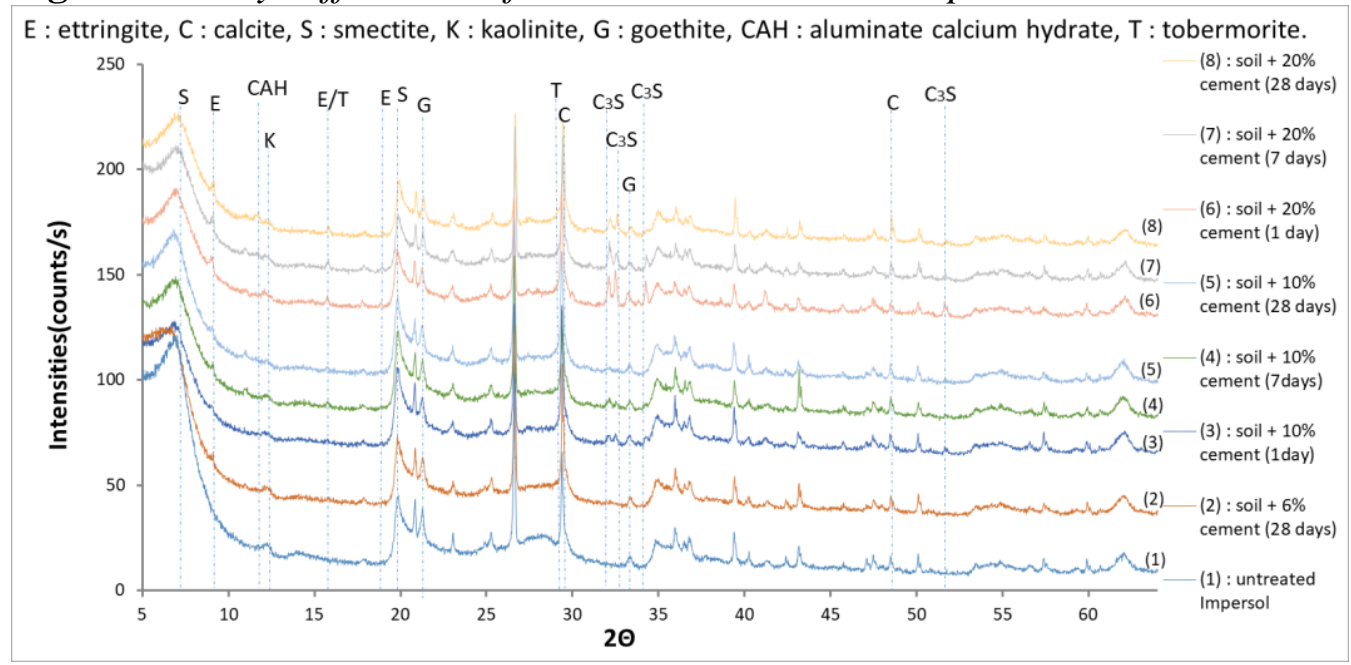

None of $6 \%$ cement treated samples' diffractograms show reflections of CAH or $\mathrm{CSH}$. A low intensity reflection of ettringite is present after 28 days curing. This can explain the fact that the better performance occurred beyond $6 \%$ of cement addition (Figures 2 and 6). In fact, at this cement content, such as for lime treatment, the calcium provided by cement is consumed by clay particles for cation exchange and the formation of new hydrates cannot occur. Treatments with $10 \%$ 
and $20 \%$ of cement leads to a calcium saturation of the soil and a cement hydration process that produce new cementitious products.

Hydration of the cement is confirmed by reducing the intensity of the $\mathrm{C}_{3} \mathrm{~S}$ reflections at d-spacing of $2.78,2.75,2.61,1.77 \AA\left(2 \theta=32^{\circ}, 32.5^{\circ}, 34.3^{\circ}, 51.8^{\circ}\right)$ with curing time. After 28 days of cure, $\mathrm{C}_{3} \mathrm{~S}$ reflections decrease significatively for treatment with $20 \%$ of cement and disappear with $10 \%$ of cement while these reflections leave after 7 days on $6 \%$ cement treated samples' diffractograms.

The results at 1 day of curing show a decrease in the intensities of smectite reflections at d-spacing of $12.4 \AA\left(2 \theta=7^{\circ}\right)$ and kaolinite reflections at d-spacing of $7.24 \AA\left(2 \theta=12.3^{\circ}\right)$. This decrease depends on the amount of cement added and curing time. The mechanisms behind this clay structure modification are the same as presented in lime treatment; clay particles' flocculation and formation of cementitious phases.

As can be seen, cement hydration occurred faster compared to lime's pozzolanic reaction and much more new calcium hydrate products are formed. This is consistent with the better results of cement treated Impersol in reducing swelling pressure after 1.5 hours and in improving the soil's strength property.

\section{Conclusions}

The results presented in this paper are part of a research program that evaluates the effectiveness of lime and cement stabilization of a highly expansive clay soil in order to understand the binder-clay interaction. Experiments carried out revealed changes in the engineering properties of treated Impersol (plasticity, swelling pressure, UCS) and in the microstructure (mineralogy).

The following main conclusions can be mentioned from the results obtained:

- Only $6 \%$ of lime addition is enough to reduce significantly the soil plasticity. Clay flocculation due to cation exchange decreases clay mineral's capacity for water absorption and therefore brings low the soil's liquid limit and its plasticity index. Cement treatment is less effective in reducing soil plasticity since clay particles flocculate less due to a lower calcium intake from the cement to the cation exchange reaction. A large amount of cement is needed to improve satisfactorily Impersol's plasticity.

- Both lime and cement treatments are effective in reducing the swelling pressure of treated Impersol. Swelling is eliminated after 2 days of curing for all percentages of binder added and after only 1.5 hours with $10 \%$ and $20 \%$ binder additions. Cation exchange and new calcium hydrate products are responsible for this improvement and changes in swelling property.

- A large increase in the unconfined compressive strength UCS is achieved by cement addition mainly due to cement hydration and the formation of $\mathrm{CSH}$ and CAH. Lime treatment enhances UCS values of treated Impersol through the pozzolanic reaction between lime and clay particles that produce $\mathrm{CAH}$. This development in strength is more relevant with 
increasing binder addition and curing time, especially for lime treatment and low kinetics of pozzolanic reaction.

- X-ray diffraction patterns allow us to confirm the presence of CAH and $\mathrm{CSH}$ in treated Impersol samples particularly at $10 \%$ and $20 \%$ binder additions and beyond 7 days curing. Clay minerals' intensity reflections decrease with binder addition confirming changes in the clay particles structure, organization and quantities. X-ray diffraction results validate the occurrence of micro-structural modifications in treated samples, leading to the observed improvement in their engineering behavior.

This study deals with an advanced analysis of interactions between pure cement and an ultra-clayey soil from one side and between lime and same ultraclayey soil from another side. Materials and dosage rates used in this study are theoretical and do not represent real context. They will help in measuring and quantifying parameters offering an advanced understanding of important physical, chemical and mechanical phenomena, which will allow optimizing design and compositions of Hydraulic road binders intended for highly clayey soil stabilization.

Based on the experimental results, the study of the effect of lime and cement on Impersol at long term (6 months of cure) is currently underway. Therefore, the evolution of the compressive strength, $\mathrm{pH}$ and electrical conductivity as well as inductively coupled plasma measurements is considered. Mineralogical tracking by XRD and scanning electron microscope (SEM) observations will be investigated to better understand the reaction between clay soil and binders.

\section{References}

Al-Mhaidib AI (2006) Swelling behavior of expansive shale - A case study from Saudi Arabia. Expansive soils - Recent advances in characterization and treatment AA AlRawas, MFA Goosen (Eds), 273-288. London: Taylor \& Francis.

Al-Mukhtar M, Lasledj A, Alcover JF (2010) Behaviour and mineralogy changes in limetreated expansive soil at $20^{\circ} \mathrm{C}$. Applied Clay Science 50(2): 191-198.

Al-Mukhtar M, Khattab S, Alcover JF (2012) Microstructure and geotechnical properties of lime-treated expansive clayey soil. Engineering Geology 139-140(Jun): 17-27.

Al-Mukhtar M, Lasledj A, Alcover JF (2014) Lime consumption of different clayey soils. Applied Clay Science 95(Jun): 133-145.

Al-Rawas AA, Hago AW, Al-Sarmi H (2005) Effect of lime, cement and Sarooj (artificial pozzolan) on the swelling potential of an expansive soil from Oman. Building and Environment 40(5): 681-687.

Bagarre E (1990) Utilisation des graveleux latéritiques en technique routière. [Use of lateritic gravel in road engineering]. Institut des Sciences et des Techniques de l'equipement et de l'environnement pour le Developpement - ISTED.

Baldovino JDJA, dos Santos Izzo RL, Moreira EB, Rose JL (2019) Optimizing the evolution of strength for lime-stabilized rammed soil. Journal of Rock Mechanics and Geotechnical Engineering 11(4): 882-891.

Cabane N (2004) Sols traités à la chaux et aux liants hydrauliques: Contribution à l'identification et à l'analyse des éléments perturbateurs de la stabilisation [Soils 
treated with lime and hydraulic binders: Contribution to the identification and analysis of disturbing elements of stabilization]. Doctoral Dissertation. Paris: Université Jean Monnet-Saint-Etienne.

Dang L, Hasan H, Fatahi B, Khabbaz H (2015) Influence of bagasse ash and hydrated lime on strength and mechanical behaviour of stabilised expansive soil. GEOQuébec 2015. J Côté, M Allard (Eds), Québec, Canada.

Dang LC, Fatahi B, Khabbaz H (2016a) Behaviour of expansive soils stabilized with hydrated lime and bagasse fibres. Procedia Engineering 143: 658-665.

Dang L, Hasan H, Fatahi B, Jones R, Khabbaz H (2016b) Enhancing the engineering properties of expansive soil using bagasse ash and hydrated lime. International Journal of GEOMATE 11(25): 2447-2454.

Goodarzi AR, Salimi M (2015) Stabilization treatment of a dispersive clayey soil using granulated blast furnace slag and basic oxygen furnace slag. Applied Clay Science 108(May): 61-69.

Goodarzi AR, Akbari HR, Salimi M (2016) Enhanced stabilization of highly expansive clays by mixing cement and silica fume. Applied Clay Science 132-133(Nov): 675684.

Ikeagwuani CC, Nwonu DC (2019) Emerging trends in expansive soil stabilisation: A review. Journal of Rock Mechanics and Geotechnical Engineering 11(2): 423-440.

Joel M, Agbede IO (2010) Mechanical-cement stabilization of laterite for use as flexible pavement material. Journal of Materials in Civil Engineering 23(2): 146-152.

Jones LD, Jefferson I (2012) Expansive soils. ICE manual of geotechnical engineering. London: ICE Publishing, 413-441.

Kalkan E (2011) Impact of wetting-drying cycles on swelling behavior of clayey soils modified by silica fume. Applied Clay Science 52(4): 345-352.

Khattab SAA (2002) Etude multi-échelles d'un sol argileux plastique traité à la chaux [Multi-scale study of a plastic clay soil treated with lime]. Doctoral Dissertation. Orléans.

Khemissa M, Mahamedi A (2014) Cement and lime mixture stabilization of an expansive overconsolidated clay. Applied Clay Science 95(Jun): 104-110.

Lasledj A (2009) Traitement des sols argileux à la chaux: processus physico-chimique et propriétés géotechniques [Treatment of clay soils with lime: physicochemical process and geotechnical properties]. Doctoral Dissertation. Orléans.

Lasledj A, Al-Mukhtar M (2008) Effect of hydrated lime on the engineering behaviour and the microstructure of highly expansive clay. In the $12^{\text {th }}$ International Conference of International Association for Computer Methods and Advances in Geomechanics.

Maubec N (2010) Approche multi-échelle du traitement des sols à la chaux-Etudes des interactions avec les argiles [Multi-scale approach to lime soil treatment-Interaction studies with clays]. Doctoral dissertation. France: Université de Nantes.

Mengue E, Mroueh H, Lancelot L, Eko RM (2017) Physicochemical and consolidation properties of compacted lateritic soil treated with cement. Soils and Foundations 57(1): 60-79.

Modarres A, Nosoudy YM (2015) Clay stabilization using coal waste and lime - Technical and environmental impacts. Applied Clay Science 116-117(Nov): 281-288.

Ouhadi VR, Yong RN, Goodarzi AR, Safari-Zanjani M (2010) Effect of temperature on the re-structuring of the microstructure and geo-environmental behaviour of smectite. Applied Clay Science 47(1-2): 2-9.

Qi S, Vanapalli SK (2015) Hydro-mechanical coupling effect on surficial layer stability of unsaturated expansive soil slopes. Computers and Geotechnics 70(Oct): 68-82.

Sasanian S, Newson TA (2014) Basic parameters governing the behaviour of cementtreated clays. Soils and Foundations 54(2): 209-224. 
Sumesh M, Kalita A, Singh B (2010) An experimental investigation on strength properties of fly ash blended soils treated with cement. Journal of Environmental Research and Development 5(2): 322-329.

Vakili AH, Selamat MR, Moayedi H (2013) Effects of using pozzolan and portland cement in the treatment of dispersive clay. The Scientific World Journal 2013. Article ID 547615 .

Verástegui-Flores RD, Di Emidio G (2014) Impact of sulfate attack on mechanical properties and hydraulic conductivity of a cement-admixed clay. Applied Clay Science 101(Nov): 490-496. 